\title{
Xylanases and cellulases biosynthesis by selected fungi in a simple and economic bio system using
} sugarcane straw

\author{
Tania Sila Campioni*, Ana Flávia de Azevedo Carvalho, Franciane Cristina \\ de Figueiredo, Douglas Fernandes da Silva, Pedro de Oliva Neto.
}

Associated Laboratory of Bioenergy Research Institute (IPBEN), Bioprocess Unit, São Paulo State University (UNESP), Av. Dom Antonio, 2100, Zip code 19806-380, Assis, SP, Brazil.

\begin{abstract}
Sugarcane straw (SS) was used in an economic biosystem to evaluate the production of xylanases and cellulases in submerged fermentation $(\mathrm{SmF})$ by axenic and mixed mode from Trichoderma and Aspergillus species. T. reesei QM9414 axenic culture reached the highest xylanase production $(90.2 \mathrm{U} / \mathrm{mL}$ ) and $0.5 \mathrm{FPU} / \mathrm{mL}$ of cellulase activity. The evaluation of agro-industrial residues on fibrolytic enzymes production was performed by a D-optimal design, and revealed the best supplementation of $100 \%$ SS, while wheat bran and citric pulp showed lower inductive effects on enzymes production. Also, the scale-up in a stirred tank showed the same yield production profile (xylanase $\sim 90 \mathrm{U} / \mathrm{mL}$ and celullase $0.6 \mathrm{FPU} / \mathrm{mL}$ ). Xylanase was characterized by an optimum $\mathrm{pH}$ of 5-6 and temperature at $50{ }^{\circ} \mathrm{C}$, and thermal stability was below $50{ }^{\circ} \mathrm{C}$. The ion $\mathrm{Mn} 2+(5$ and $10 \mathrm{mM}) \mathrm{had}$ a stimulatory effect on xylanase activity. The biobleaching application showed that $30 \mathrm{U} / \mathrm{g}$ of xylanases during 15 min decreased Kappa number in 9.37. These results indicate SS as an alternative substrate for fungi fibrolytic enzymes production and the xylanase with low cellulase extract as a potential biobleaching application. Keywords - sugarcane straw, xylanase, cellulase, axenic and mixed cultures, fibrolytic enzymes.
\end{abstract}

\section{INTRODUCTION}

Due to broadened use of renewable energy sources for biofuels and high-value products production in wordwide, including organic wastes mainly produced by agricultural countries, demand for green technologies has increased replacing the extensive usages of fossil fuels (Ferreira-Leitão et al., 2010; Carpio et al., 2019). Sugarcane cultivation is one of the major agricultural activities in Brazil which produced 620.4 million tons in 2018-2019 (Conab, 2019). During the sugarcane burning harvest system, almost $27 \mathrm{~kg}$ of carbon dioxide is released into the atmosphere per ton of sugarcane processed, related to burn (40\%), fertilizers (20\%) and fossil fuels use (18\%), thus this quantity can decrease using no-burning system (Figueiredo et al., 2010). The São Paulo state law number 11.241/ 2002 established that, after 2017, 80\% of sugarcane, harvesting should be mechanized and after 2021, no more burning will be permitted in mechanized areas. As a consequence of this new system implantation, almost $15 \mathrm{Mg} \mathrm{ha}^{-1}$ dry biomass has been left in the field yearly, mainly SS (sugarcane straw) residue (Hassuani et al., 2005).

Straw represents around one-third of the total primary energy of the sugarcane crop, with a composition very similar to the widely used bagasse, mainly cellulose, hemicellulose and lignin, 30, 30 and 25\%, respectively (Leal et al., 2013). The straw residue in the soil range from positive impacts, such as increase in the macrofauna (mainly worms and ants), nutrients recycling, water storage, carbon accumulation, control of soil erosion and weed infestation, to negative impacts, such as increase in pest populations and biomass loss production (Leal et al., 2013; Carvalho et al., 2017). In fact, a research showed that $50 \%$ of SS residue in the soil is necessary to improve the yield of sugarcane crop but the other $50 \%$ should be recovered to be used in eco-friendly processes (Aquino et al., 2017). Depending on the amount and characteristics, that residue could be collected to produce energy or coproducts such as enzymes (Carvalho et al., 2016; Silva et al., 2018), xylitol (Hernández-Pérez et al 2016), and biodegradable products such as cups, and straws (Gankin, 2019).

In addition, the enzyme technology has continuously replaced the traditional chemical processes in many areas, especially fine chemical and pharmaceutical industries (Choi et al., 2015). The global market for industrial enzymes expects to increase from nearly $\$ 5.5$ billion in 2018 to $\$ 7.0$ billion in 2023 with a compound annual 
growth rate (CAGR) of 4.9\% for 2018-2023 (Dewan et al., 2017). The importance of enzyme technology includes the knowledge of fermentation and downstream process, and a high number of available enzymes and applications are developed by the improvement of these technologies ( $\mathrm{Li}$ et al., 2012). In this sense, the use of agro-industrial residues as carbon source for enzyme biosynthesis by microorganisms, which have potential to decrease the production costs and the final price of enzymes (Salmon et al., 2016; Abdullah et al., 2015). Currently, cellulases represent the third higher industrial enzyme production, and their applications are in cotton, paper recycling, juice extraction, detergent and feed industry (Acharya and Chaudhary, 2012). Other important fibrolytic enzymes are the xylanases, responsible for the hemicellulose hydrolysis. Filamentous fungi produce xylan-degrading enzymes, which is the main interest to industrial purposes due to its low-cost production and the final price of the product as well (Abdullah et al., 2015). Mesophilic fungus as the genera Aspergillus and Trichoderma have a remarkable importance on xylanases and cellulases improvement production, since they can be cultivated in mixed culture (Ahamed and Vermette 2008; Wen et al., 2005; Dhillon et al., 2011).

Although the efficiency of SS as a feedstock and inducer for cellulase production by some microorganisms were reported to Streptomyces sp SLBA-08 (Macedo et al., 2013) and Trichoderma citrinoviride (Guerra et al., 2006), in literature there is a lack studies of SS as feedstock for xylanase and cellulase production by $T$. reesei, Trichoderma harzianum and Aspergillus fumigatus in $\mathrm{SmF}$ (submerged fermentation).

In the present study, fibrolytic enzymes production was conducted considering the formulation of the culture medium with SS agro-residue and fungi from Trichoderma and Aspergillus genera, in axenic and mixed cultures. In addition, the biochemical characterization of the xylanases produced in the best conditions was performed considering biobleaching and future application.

\section{MATERIAL AND METHODS}

\subsection{Microorganisms and substrates}

The microorganisms tested in axenic cultures were: Trichoderma reesei (Tropical Culture Collection of André Tosello Foundation CCT -2768), T. reesei QM9414, Trichoderma harzianum N51, T. harzianum FS09, Aspergillus fumigatus M51 and A. fumigatus U2370. These cultures were selected in a previous study as the best producers of fibrolytic enzymes (Carvalho et al., 2015). They were cultured in plates containing $3.9 \%$ (w/v) Potato Dextrose Agar (PDA) medium for 7 days at $28{ }^{\circ} \mathrm{C}$ and stored at $4{ }^{\circ} \mathrm{C}$. Lignocellulosic substrates were used as carbon source in the culture medium. The SS was obtained from Água Bonita Mill, Tarumã-SP, Brazil, pretreated (autoclave at $121{ }^{\circ} \mathrm{C}, 15 \mathrm{~min}, 1 \mathrm{~atm}$ ), and milled (14 mesh). The citrus pulp (CP) (from Citrovita, CatanduvaSP, Brazil) was milled (14 mesh), and wheat bran (WB) was used without any previous treatment (from Moinho Nacional, Assis-SP, Brazil).

2.2 Selection of microorganisms in axenic and mixed cultures

The axenic and mixed strains were cultivated in Erlenmeyer flasks $(250 \mathrm{~mL})$ by $\mathrm{SmF}$ containing $80 \mathrm{~mL}$ medium $(\mathrm{m} / \mathrm{v}): 3.0 \%$ pretreated $\mathrm{SS}, 0.1 \%\left(\mathrm{NH}_{4}\right)_{2} \mathrm{SO}_{4}$ $0.0017 \% \mathrm{MgSO}_{4} \cdot 7 \mathrm{H}_{2} \mathrm{O}, 0.1 \% \mathrm{~K}_{2} \mathrm{HPO}_{4}, 0.0028 \% \mathrm{ZnSO}_{4}$ $0.1 \% \mathrm{NH}_{4} \mathrm{H}_{2} \mathrm{PO}_{4}, 0.06 \% \mathrm{KCl}, 0.1 \%$ yeast extract and $0.1 \%$ sucrose at pH 4.5 (Silva et al., 2013). Each fungus spores suspension was prepared by incubating the cultures on PDA plates at $28{ }^{\circ} \mathrm{C}$ for about 10 days, until sufficient sporulation was observed. The spores were harvested using $0.1 \%$ Tween 80 solution $(\mathrm{v} / \mathrm{v})$ for inoculation purposes (about $1 \times 10^{6}$ cells $/ \mathrm{mL}$ ). Flasks were inoculated and incubated at $28{ }^{\circ} \mathrm{C}$, in an orbital shaker at $180 \mathrm{rpm}$ for $360 \mathrm{~h}$. The biomass was separated by $15 \mathrm{~min}$ centrifugation at $4{ }^{\circ} \mathrm{C}$ and $2900 \mathrm{x} \mathrm{g}$. The liquid fraction was used as a crude enzymes extract. The binary mixtures of $T$. harzianum FS09 and A. fumigatus M51; $T$. harzianum FS09 and $T$. reesei QM9414; T. reesei QM9414 and A. fumigatus M51; as well as the ternary mixture of $T$. harzianum FS09, T. reesei QM9414 and $A$ fumigatus M51; in concentration of spores at $1 \times 10^{6}$ cells/mL for each one, were combined since they are considered the best xylanase and cellulase producers of this study.

2.3 Formulation of culture medium with mixtures of agro-industrial residues for fibrolytic enzymes production

The SmF of selected microorganism was performed in Erlenmeyer flasks $(250 \mathrm{ml}$, with $80 \mathrm{~mL}$ of medium described previously (section 2.2) during $288 \mathrm{~h}$ of incubation in a shaker at $28^{\circ} \mathrm{C}$ and $180 \mathrm{rpm}$. D-Optimal mixture design was performed in order to evaluate the effect of individual substrates and the interactions among them in ternary mixtures on xylanase and cellulase production (Fernández-Núñez et al., 2016; Nunes et al., 2017). The number of experimental combinations in each experimental design was enough to fit special cubic models for response variables. The parameters and restrictions of the mixtures were: SS (60-100\% w/w range), $\mathrm{CP}(0-40 \% \mathrm{w} / \mathrm{w}$ range) and $\mathrm{WB}(0-20 \% \mathrm{w} / \mathrm{w}$ range). A control experiment using $100 \%(\mathrm{w} / \mathrm{v})$ of each substrate was performed at the same conditions. The D- 
optimal experimental design was set up with restrictions and analyzed using Design-Expert software (DesignExpert $^{\circledR}$ software, version 10, Stat-Ease, Inc., Minneapolis, MN, USA). The statistical results were made considering a significance level of 0.05 . The strength of linear relationships between actual and predicted values by different models was assessed using the linear correlation coefficient $\left(\mathrm{R}^{2}\right)$. The xylanolytic activity in ternary mixtures of agro-industrial residues D-Optimal experimental design was optimized using a desirability function. The optimization criterion was to maximize xylanase activity according to a fitted polynomial for this variable.

\subsection{Stirred tank bioreactor culture}

The enzyme production by selected microorganism was scaled-up in $2 \mathrm{~L}$ BioFlo 115 fermenter (New Brunswick, New Jersey, USA) using medium and inoculation as previously described (section 2.2), working volume of $1.5 \mathrm{~L}$, and Rushton impeller. The culture conditions were $28{ }^{\circ} \mathrm{C}, 1.7$ volume of air per volume of medium per minute (vvm), $\mathrm{pH} 4.5$ for $288 \mathrm{~h}$. Dissolved oxygen was measured by an oxygen electrode and $\mathrm{pH}$ was measured and controlled with $1.0 \%(\mathrm{v} / \mathrm{v}) \mathrm{H}_{2} \mathrm{SO}_{4}$ and $1.0 \mathrm{M} \mathrm{NaOH}$.

\subsection{Biochemical characterization of fungal xylanase}

The biochemical characterization of xylanases produced from selected microorganism in SmF using selected substrate as described in the following protocols (Carvalho et al., 2006; Carvalho et al., 2010).

\subsubsection{Optimum $\mathrm{pH}$ and stability}

Optimum $\mathrm{pH}$ was evaluated by measuring enzyme activity at $50{ }^{\circ} \mathrm{C}$ using different buffers: sodium acetate ( $\mathrm{pH}$ 3.0-6.0), sodium phosphate $(\mathrm{pH}$ 6.0-8.0), Tris- $\mathrm{HCl}$ (pH 8.0-9.0), and glycine- $\mathrm{NaOH}(\mathrm{pH} 9.0-11.0)$ and a reaction mixture containing $0.65 \mathrm{~mL} 0.5 \%(\mathrm{w} / \mathrm{v})$ xylan in $0.25 \mathrm{M}$ buffer and $0.10 \mathrm{~mL}$ crude enzyme. For $\mathrm{pH}$ stability, crude enzyme extract was diluted (1:1) in buffers and maintained at $25{ }^{\circ} \mathrm{C}$ for 20,40 and $60 \mathrm{~min}$. An aliquot was used to determine the remaining activity (section 2.6).

\subsubsection{Optimum temperature and thermostability}

The optimal temperature was determined by incubating the reaction mixture at $20-70{ }^{\circ} \mathrm{C}(10 \mathrm{~min})$ and assaying the enzyme activity at the optimum $\mathrm{pH}$, in the same reaction mixture (2.6). For thermostability assay, the enzyme solution was incubated at various temperatures $\left(20-70{ }^{\circ} \mathrm{C}\right.$ ) for 20,40 and $60 \mathrm{~min}$ at $\mathrm{pH} 5.0$ in sealed tubes to prevent evaporation. The enzyme solution was maintained at these temperatures and times. Aliquots were removed and placed on ice before assaying for residual enzyme activity at optimum $\mathrm{pH}$ and temperature.

\subsubsection{Effect of ions and EDTA}

The effects of ions $\left(\mathrm{Cu}^{+2}, \mathrm{Mg}^{2+}, \mathrm{Mn}^{2+}, \mathrm{Zn}^{2+}, \mathrm{Fe}^{3+}\right.$, $\mathrm{Ag}^{+}$) and EDTA (Ethylenediamine tetra-acetic acid) on xylanase activity were evaluated. Solutions concentrations of 5 and $10 \mathrm{mM}$ were added to the reaction mixture at the concentration of $0.2 \%(\mathrm{v} / \mathrm{v})$. The calculation of the percentage of enzyme activity was performed based on the reference sample without addition of any ion.

\subsection{Enzymes activity assay}

Xylanase activity was assayed at $50{ }^{\circ} \mathrm{C}$ in a reaction with $0.1 \mathrm{~mL}$ raw enzyme extract and $0.65 \mathrm{~mL}$ of $0.5 \%$ $(\mathrm{m} / \mathrm{v})$ xylan Birchwood solution (Sigma-Aldrich) in $250 \mathrm{mM}$ sodium acetate buffer, at $\mathrm{pH} 5$ for $10 \mathrm{~min}$ (Bailey et al., 1993). The reducing sugar concentration was quantified by the dinitrosalicylic acid (DNS) method (Miller, 1960). One unit (U) of xylanase activity was defined as the amount of enzyme to release $1 \mu \mathrm{mol}$ of reducing sugar per minute per $\mathrm{mL}$ of reaction. The cellulase activity was determined by Ghose (1987). One FPU here is defined as $\mu$ moles glucose equivalents released from Whatman $n^{\circ}$. 1 per min averaged over 60 min, considering the low enzyme concentration in the raw enzymatic extract.

\subsection{Biobleaching}

Xylanase from $T$. reesei QM9414 was studied for biobleaching process of Kraft pulp as well as to evaluate its potential use as biobleaching agent. The amount of enzyme used for hydrolysis was 30 units of enzyme per gram of pulp samples. Test conditions were performed in a sealed polyethylene bags with sodium acetate buffer $(\mathrm{pH}$ 5.0), at $50{ }^{\circ} \mathrm{C}$ for $15 \mathrm{~min}$ (soaking stage). Treatment started by diluting the enzyme in the same buffer (pre-heated at 50 ${ }^{\circ} \mathrm{C}$ ), adding the solution on pulp samples and then mixed by kneading the bags during $30 \mathrm{~s}$. The final pulp content in the reaction mixture was $3 \%$. Controls were prepared by adding distilled water instead of enzyme. After the enzymatic hydrolysis, the bags were boiled at $100{ }^{\circ} \mathrm{C}$ for 5 min to disable the enzymes, cooled and filtered on a Büchner funnel to form paper sheets, used for kappa number analysis. 


\section{RESULTS AND DISCUSSION}

3.1 Selection of fungi for fibrolytic enzymes production in axenic and mixed cultures using SS as a carbon source

\subsubsection{Axenic fungal cultures}

All tested microorganisms showed xylanases and cellulases production using SS substrate as the sole carbon source in SmF (Fig. 1A and 1B). T. reesei QM9414 strain stood out compared to other fungi tested, reaching the highest production of $90 \mathrm{U} / \mathrm{mL}$ for xylanase and 0.56 FPU/mL for cellulase at $288 \mathrm{~h}$ of fermentation. Nevertheless, the fungi A. fumigatus M51 and A. fumigatus U2370 also showed good results for xylanases production, approximately $70 \mathrm{U} / \mathrm{mL}$ (Fig. 1A). However, after $288 \mathrm{~h}$ the enzymes activities decreased, probably due to protease presence in SmF (Silva et al., 2016; Haab et al., 1999). In literature, a higher concentration of xylanase was obtained when compared to $3.38 \mathrm{U} / \mathrm{mL}$ at $120 \mathrm{~h}$ of cultivation by Trichoderma inhamatum (Silva et al., 2015). Also, xylanase activity achieved $43.7 \mathrm{U} / \mathrm{mL}$ at $144 \mathrm{~h}$ of cultivation by $T$. reesei CCT $2768,35 \mathrm{U} / \mathrm{mL}$ by $A$. fumigatus $\mathrm{M} 51$ and $28 \mathrm{U} / \mathrm{mL}$ by $A$. fumigatus $\mathrm{U} 2370$, using sugarcane bagasse in culture medium (Carvalho et al., 2010).

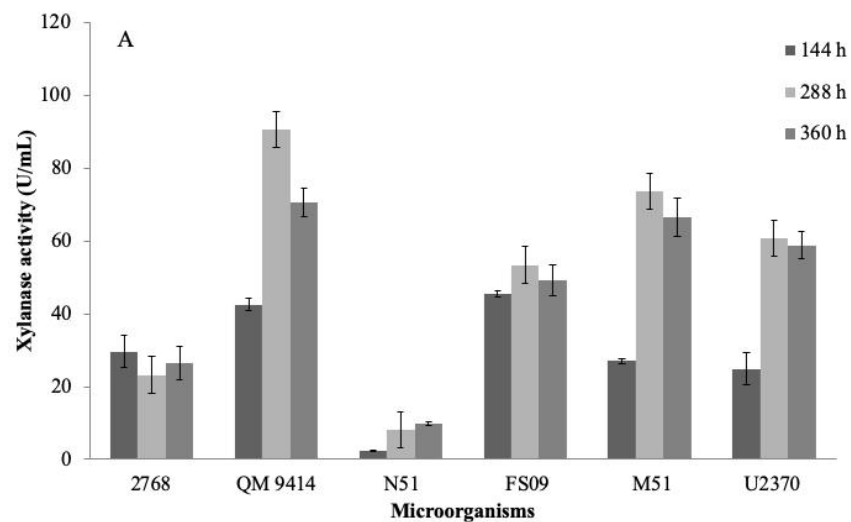

The fungi T. harzianum FS09, A. fumigatus M51 and T. reesei $\mathrm{QM} 9414$ were the best cellulases producers, 0.2 , 0.4 and $0.6 \mathrm{FPU} / \mathrm{mL}$ at $288 \mathrm{~h}$, respectively (Fig. 1B). However, these results obtained to cellulases were lower compared to those found in other studies such as Zhang et al (2014) (0.93 FPU/mL, $96 \mathrm{~h})$ and Xiong et al (2016) (2.33 FPU/mL, $144 \mathrm{~h}$ ) also produced by Trichoderma species, although in these studies were used different substrates as pretreated corn stover and a synthetic medium, respectively. The fact that $T$. reesei QM 9414 produced low cellulases is important for pulp biobleaching application of xylanases for reducing the chlorinated compounds in the paper mills.

\subsubsection{Mixed fungal cultures}

The mixed fungal and axenic cultures were compared in the present study. Since the Trichoderma and Aspergillus co-culture system has been reported in literature (Ahamed and Vermette, 2008; Wen et al., 2005), the followed mixtures were proposed: T. reesei QM 9414, A. fumigatus M51 and T. harzianum FS09. Xylanase and cellulase production profile by mixed cultures during 360 $\mathrm{h}$ of cultivation were evaluated (Fig. 2A and 2B).

Fig. 1: A) Profile of xylanase production by fungi: T. reesei 2768 (2768), T. reesei QM9414 (QM9414), T. harzianum N51 (N51), T. harzianum FS09 (FS09), A. fumigatus M51 (M51) and A. fumigatus U2370 (U2370), in SmF using SS as substrate $\left(28^{\circ} \mathrm{C}, \mathrm{pH} 4.5,180 \mathrm{rpm}\right)$. Each bar value was the average of three replicate experiments, and the error bars show the data ranges. B) Profile of cellulase production by fungi: T. reesei 2768 (2768), T. reesei QM9414 (QM9414), T. harzianum N51 (N51), T. harzianum FS09 (FS09), A. fumigatus M51 (M51) and A. fumigatus U2370 (U2370), in SmF using $\mathrm{SS}$ as substrate $\left(28^{\circ} \mathrm{C}, \mathrm{pH} 4.5,180 \mathrm{rpm}\right)$. Each bar value was the average of three replicate experiments, and the error bars show the data ranges.

When fibrolytic enzymes biosynthesis from these mixed cultures were compared to axenic culture (Fig. 1-2), the enzyme activities of mixed cultures were lower. However, this result was not expected according to literature (Ahamed and Vermette, 2008; Wen et al., 2005; Dhillon et al., 2011), since the mixed cultures with Trichoderma and Aspergillus genera resulted in a complete enzymatic pool that acts synergistically better in substrate degradation compared to respective axenic culture. According to Duff et al. (1987), fungi species started a substrate competition between them, consequently blocking the enzyme production. The fibrolytic enzymes biosynthesis by Aspergillus inhibited the enzymes biosynthesis of Trichoderma, probably due 
to the catalysis of those enzymes already produced. Proteases or endotoxins biosynthesis could degrade or inhibit the cellulases. In addition, a competition between these microorganisms for the same nutrients in the medium is another hypothesis. The carbon source is reported an important parameter to a successful mixed culture (Dhillon et al., 2011).

Although the results were lower than axenic cultivation for xylanase production, the mixed culture $T$. reesei QM 9414 and A. fumigatus M51 reached the maximum value of $60 \mathrm{U} / \mathrm{mL}$ (Fig. 2A). On the other hand, it was better than produced by Zhang et al. (2014) (2.5 U/mL), but with another strain (T. reesei Rut C-30). These authors also reported a slightly improvement on cellulase production $(22.89-24.17 \mathrm{U} / \mathrm{g})$ respectively from axenic to mixed cultures, in solid state fermentation (SSF), while the substrate consumption was better in mixed culture. T. reesei mutant and A. niger in mixed culture resulted in an improvement on enzymes production comparing to single culture by non-mutant strain (Gutierrez-Correa et al., 1999). A synergy in mixed culture of Trichoderma and Aspergillus was also verified for substrate degradation and consequently a higher enzyme synthesis (Ahamed and Vermette, 2008). However, the culture of $T$. reesei and A. phoenics ATCC329 xylanase was worse compared to axenic culture in the present study (Wen et al., 2005). Enzymes production by a single culture is preferred to achieve the better substrate degradation from its synergic effect, despite the mixed culture improves cellulases and $\beta$ glucosidases production by $T$. reesei QM9414 and $A$ terreus SUK-1 (Wen et al., 2005). In fact, other authors reported the competition by Trichoderma and Aspergillus to the same nutrients in the medium in a mixed culture (Ahamed and Vermette, 2008; Duff et al., 1987; Anthony et al., 2016). As T. reesei showed a great production of xylanases, this strain was selected for the next steps of this work with emphasis for xylanases.

For fibrolytic enzymes production, $3 \%(\mathrm{~m} / \mathrm{v})$ of the substrates SS, CP and WB were evaluated isolated by $T$. reesei QM9414 in SmF medium (Table 1). The culture medium formulated by SS only as substrate showed a higher performance for xylanases biosynthesis $(90 \mathrm{U} / \mathrm{mL})$ than other residues. For cellulases production, the cultures of T. reesei QM9414 also showed a highest preference for SS (0.6 FPU/mL) (Table 1).

Table 1: Fibrolytic enzymes production by T. reesei QM 9414 using agro-industrial residues and its respective chemical composition.

\begin{tabular}{|c|c|c|c|c|c|c|}
\hline Substrate** & $\begin{array}{c}\text { Xylanase } \\
\text { activity } \\
(\mathrm{U} / \mathrm{mL}) \\
\end{array}$ & $\begin{array}{c}\text { Cellulase } \\
\text { activity } \\
\text { (FPU/mL) }\end{array}$ & $\begin{array}{l}\text { Cellulose } \\
(\%) \mathrm{w} / \mathrm{w}\end{array}$ & $\begin{array}{l}\text { Hemicellulose } \\
(\%) \text { w/w }\end{array}$ & $\begin{array}{c}\text { Lignin } \\
(\%) \\
\text { w/w } \\
\end{array}$ & Reference \\
\hline $\begin{array}{l}\text { Sugarcane } \\
\text { Straw }\end{array}$ & $90.6 \pm 7.04$ & $0.56 \pm<0.1$ & 33.77 & 27.38 & 21.28 & $\begin{array}{c}\text { Szczerbowski, } \\
\text { et al., } 2014\end{array}$ \\
\hline $\begin{array}{l}\text { Wheat } \\
\text { bran }\end{array}$ & $37.7 \pm 4.23$ & $<0.10 \pm<0.1$ & 22.3 & 32 & 4 & $\begin{array}{l}\text { Marín et al., } \\
2007\end{array}$ \\
\hline Citrus pulp & $31.0 \pm 5.87$ & $0.10 \pm<0.1$ & 24.52 & 7.57 & 7.51 & $\begin{array}{c}\text { Rahman et al., } \\
2017\end{array}$ \\
\hline
\end{tabular}

*The results are related with the average and standard deviation of three experiments. $* *(3 \% \mathrm{w} / \mathrm{v})$. 

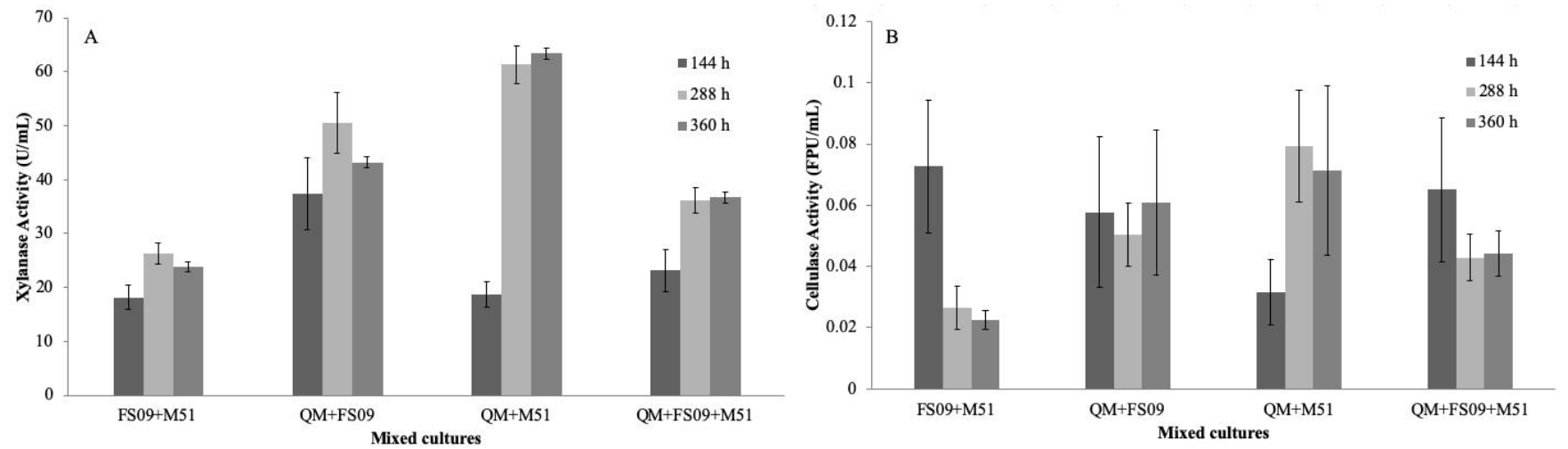

Fig. 2: A) Profile of xylanase production in mixed cultures: T. harzianum FS09 + A. fumigatus M51 (FS09+M51); T. harzianum FSO9 + T. reesei QM 9414 (QM+FS09); T. reesei QM 9414+ A. fumigatus M51 (QM+M51); T. harzianum FS09

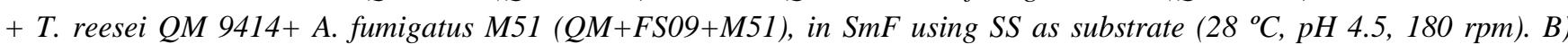
Profile of cellulase production in mixed cultures: T. harzianum FS09 + A. fumigatus M51 (FS09+M51); T. harzianum FS09 + T. reesei QM 9414 (QM+FS09); T. reesei QM 9414+ A. fumigatus M51 (QM+M51); T. harzianum FSO9 + T. reesei QM $9414+$ A. fumigatus M51 (QM+FS09+M51), in SmF using SS as substrate (28 ${ }^{\circ} \mathrm{C}, \mathrm{pH} 4.5,180$ rpm). Each bar value was the average of three replicate experiments, and the error bars show the data ranges.

3.2 The effect of the mixture of agro-industrial residues in formulated media for fibrolytic enzyme production by $T$. reesei $\mathrm{QM} 9414$

The use of WB as substrate was proposed since in literature was observed higher xylanase production in SSF culture (Dhillon et al., 2011; Guimarães et al., 2013) for this residue. The substrates compositions (Table 1) suggest that $\mathrm{CP}$ and WB should be more easily hydrolyzed due to their low lignin content. In addition, this fact is responsible for a better xylanases production in SS, since SS residue has high level of lignin makes the degradation of the fiber more difficult and it demands more fibrolytic enzymes.

In the second set of experiments, a D-Optimal mixture experimental design was used to evaluate the synergistic or antagonistic effects of the mixed carbon sources in SmF to produce fibrolytic enzymes by $T$. reese $i$ QM 9414 in 12 days (Table 2). When xylanase and cellulase activities were evaluated, for ternary mixtures of these substrates, were modeled in D-optimal design, cubic models were satisfactorily fitted to the experimental data (model significance tests, $\mathrm{p}<0.05$ and lack of fit tests, $\mathrm{p}>0.05)$.
Xylanase
activity
$(\mathrm{U} / \mathrm{mL})$
$89.18 * \mathrm{~A}+80.18 * \mathrm{~B}+1408.6 * \mathrm{C}-3.97 * \mathrm{AB}-2716.56 * \mathrm{AC}-$
$2693.27 * \mathrm{BC}+3926.94 * \mathrm{ABC}+269.98 * \mathrm{AB}(\mathrm{A}-$
B) $+1683.22 * \mathrm{AC}(\mathrm{A}-\mathrm{C})+1.798 * \mathrm{BC}(\mathrm{B}-\mathrm{C})$ Eq. (1)
Cellulase activity $(\mathrm{U} / \mathrm{mL})=0.52 * \mathrm{~A}+0.43 * \mathrm{~B}+10.87 * \mathrm{C}$ -
$0.11 * \mathrm{AB}-21.73 * \mathrm{AC}-$
$21.4734 * \mathrm{BC}+30.88 * \mathrm{ABC}+1.88 * \mathrm{AB}(\mathrm{A}-\mathrm{B})+11.89 * \mathrm{AC}(\mathrm{A}-$
C) $+13.45^{*}$ BC(B-C). Eq.(2)

The equations for xylanase and cellulase activities (Equations 1-2 for actual values) in conjunction with contour Graphs (Fig. 3A and 3B) showed the major contribution of SS for higher values of fibrolytic enzymes activities.

The SS influence on xylanase activity was noticed that activity increased with higher substrate concentration, while for $\mathrm{CP}$ residue a slight increment on xylanase activity was observed. The substrate WB was not interesting for this purpose since the results were not satisfactory.

Table 2: Results derived from D-optimal experimental design for ternary mixtures of SS, CP and WB as carbon sources in SmF by T. reesei QM9414 (pH 4.5, $\left.28^{\circ} \mathrm{C}, 288 \mathrm{~h}\right)$.

\begin{tabular}{llllll}
\hline Experiment & $\begin{array}{l}\text { Sugarcane Straw } \\
(\boldsymbol{\%} \mathbf{m} / \mathbf{m})\end{array}$ & $\begin{array}{l}\text { Citrus Pulp } \\
(\boldsymbol{\%} \mathbf{m} / \mathbf{m})\end{array}$ & $\begin{array}{l}\text { Wheat Bran } \\
(\boldsymbol{\%} \mathbf{m} / \mathbf{m})\end{array}$ & $\begin{array}{l}\text { Xylanase } \\
\text { Activity } \\
(\mathbf{U} / \mathbf{m L})\end{array}$ & $\begin{array}{l}\text { Cellulase } \\
\text { Activity } \\
(\mathbf{F P U} / \mathbf{m L})\end{array}$ \\
\hline 1 & 80.0 & 0.0 & 20.0 & 69.4 & 0.3 \\
2 & 75.0 & 15.0 & 10.0 & 83.9 & 0.4 \\
3 & 60.0 & 20.0 & 20.0 & 70.0 & 0.3
\end{tabular}




\begin{tabular}{llllll}
4 & 60.0 & 40.0 & 0.0 & 81.8 & 0.4 \\
5 & 60.0 & 20.0 & 20.0 & 71.8 & 0.3 \\
6 & 90.0 & 0.0 & 10.0 & 67.3 & 0.2 \\
7 & 82.5 & 7.5 & 10.0 & 93.3 & 0.4 \\
8 & 66.67 & 20.0 & 13.33 & 61.2 & 0.2 \\
9 & 60.0 & 40.0 & 0.0 & 78.4 & 0.4 \\
$10(\mathrm{C})$ & 100.0 & 0.0 & 0.0 & $\mathbf{9 0 . 2}$ & $\mathbf{0 . 5}$ \\
$11(\mathrm{C})$ & 100.0 & 0.0 & 0.0 & 88.1 & 0.5 \\
12 & 80.0 & 20.0 & 0.0 & 83.9 & 0.4 \\
13 & 70.0 & 10.0 & 20.0 & 84.7 & 0.4 \\
14 & 67.5 & 27.5 & 5.0 & 88.2 & 0.4 \\
15 & 80.0 & 20.0 & 0.0 & 83.5 & 0.5 \\
\hline
\end{tabular}

The math models are expressed in Eq. 1-2, with coded variables showing the enzymatic activities as function of: $\mathrm{A}=\mathrm{SS}(\mathrm{w} / \mathrm{w}), \mathrm{B}=\mathrm{CP}(\mathrm{w} / \mathrm{w})$, and $\mathrm{C}=\mathrm{WB}$ $(\mathrm{w} / \mathrm{w})$. According to ANOVA, each activity response desired, xylanase and cellulase activities produced were statistically significant $(\mathrm{p}<0.05)$, respectively, for the cubic math models with high Regression coefficient $\left(\mathrm{R}^{2}{ }_{\text {adj }}=0.95,0.93\right)$.

Regarding the cellulase production, SS in a relatively higher concentration presented great activities. However, WB did not represent any synergic effect with other substrates. CP presented a positive effect on cellulase activity within the range interactions. On the other hand, these results are in disagreement with some authors that found an improvement on enzymes production in optimization studies of mixed substrates. Das et al. (2013) showed cellulase production increased 1.3-fold after the medium optimization, containing WB and rice straw by $A$. fumigatus ABK9. WB also performed a positive effect $(21 \%)$ in the xylanase production by A. flavus (Guimarães et al., 2013).

Considering the final purpose of the use of crude enzymatic extract rich in xylanases and poor in cellulases, which are an important characteristic for biobleaching of kraft pulp (Guimarães et al., 2013; Nagar et al., 2010), the optimization of parameters was adjusted to reach a maximum of xylanases and low cellulases production. The optimal set of factors to maximize xylanase production by $T$. reesei was $100 \% \mathrm{SS}$, which the experiment 10 reached $90.2 \mathrm{U} / \mathrm{mL}$ (Table 2). The most significant results were achieved with $100 \%$ SS with desirability predicted for the model was 0.92 . The result was validated (in triplicate) in the same conditions $(100 \%$ SS). The predicted result from the desirability function was $89.2 \mathrm{U} / \mathrm{mL}$ and the result obtained, $90.2 \mathrm{Um} / \mathrm{mL}$, presented no significant difference (Anova+Tukey, $\mathrm{p}>0.05$ ). The crude enzymes extract under this condition was rich in xylanases and poor in cellulases, a ratio of 1:0.005 U/mL, respectively.

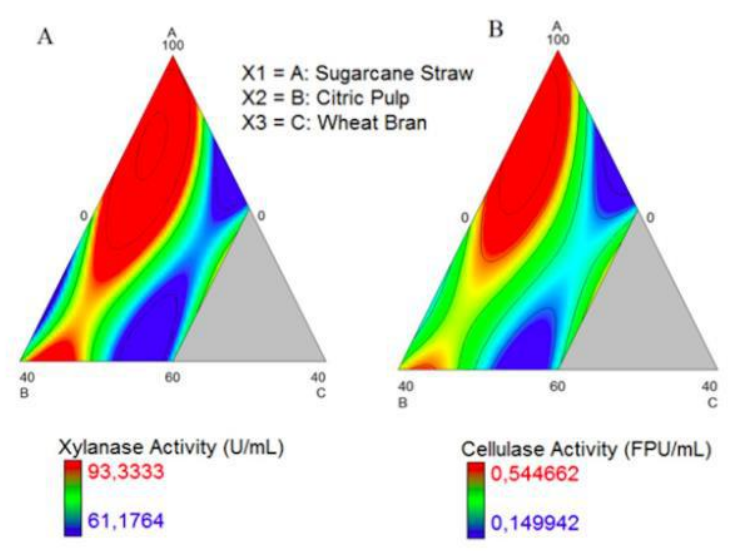

Fig. 3: Contour plots of responses generated by the interactions of the $A=S S(w / w) ; B=C P(w / w) ; C=W B$ $(w / w)$, on fibrolytic activities. A) Xylanase activity and $B$ ) Cellulase activity produced in SmF by T. reesei QM9414 using SS, $C P$ and $W B$ as substrates $\left(28{ }^{\circ} \mathrm{C}, \mathrm{pH} 4.5,180\right.$ rpm).

Regarding the xylanase application on kraft pulp biobleanching, Campioni et al. (2019) studied xylanase extract produced by $T$. reesei QM9414 in SmF with SS and optimized the biobleanching parameters. The best conditions were $30 \mathrm{U} / \mathrm{g}$ of xylanase, at $\mathrm{pH} 5$, at $50{ }^{\circ} \mathrm{C}$ during $30 \mathrm{~min}$ and resulted a $12.5 \%$ of Kappa number reduction. After the xylanase biobleaching, the final chlorine dioxide consumption reduced to $10 \%$, maintaining the same brightness compared to control on the subsequent chemical process. In addition, an important parameter for biobleanching application is the xylanase combined with low cellulase concentration or 
even no cellulase activity, otherwise, higher amount of this enzyme could degrade the pulp.

It is known about the successful application of enzymes depends not only on the substrate choice but a simple bioprocess and mainly a low-cost production as well. As mentioned previously (section 1), regarding the transition of no sugarcane burning on harvest system (São Paulo State No. 11.241/2002), the SS residue has been left large amounts on fields, which influenced the dynamics of sugarcane production in several aspects (Carvalho et al., 2017). Additionally, SS has been considered a low-cost residue, which the average of value of US \$9.38/ton (Carpio et al., 2019). In this sense, several lignocellulosic agro-industrial residues have been widely evaluated as substrate for xylanase production, such as sugarcane bagasse, WB, sawdust, soy flour, maize straw and others (Knob et al., 2013). Although the use of agro-industrial residues has been extensity described in literature, there is the concern about multiple and complex process steps, consequently become more expensive and difficult to scale up. For example, the substrate pretreatment procedures, waste of extensive washing with distilled water (Knob et al., 2014), chemical pretreatments and in some cases they can generate other toxic compounds for microorganisms and become difficult to find an appropriate destination (Robl et al., 2015). Therefore, this study is a cost effective and simple using SS as a potential substrate for fibrolytic production by $T$. reesei QM9414 and its biobleaching application. After the selection of microorganism and agro-industrial residue used as carbon sources, the enzymatic production was scaled up in bioreactor using $1.5 \mathrm{~L}$ working volume and controlled conditions, resulting in $88.02 \pm 4.54 \mathrm{U} / \mathrm{mL}$ and $0.41 \pm<0.1 \mathrm{FPU} / \mathrm{mL}$, for xylanase and cellulase respectively, proving a high level of xylanase production using $100 \%$ of SS by T. reesei QM9414 can be obtained by this simple and economical bioprocess. On the other hand, the enzyme production losses were detected in scaling-up of $T$. harzianum $\mathrm{P} 49 \mathrm{P} 11$ in $\mathrm{SmF}$ using sugarcane bagasse in stirred tank bioreactor (Haab et al., 1990).

3.3 Xylanases biochemical characterization

The enzymatic extract produced by $T$. reesei QM9414 cultivated in SS medium (12 culture days) showed the highest xylanase activity at pH $5(100 \mathrm{U} / \mathrm{mL})$ (Fig. 4A). The lower range ( $\mathrm{pH} \mathrm{3-4)} \mathrm{and} \mathrm{basic} \mathrm{pH}(\mathrm{pH} 8-$ 11) strongly decreased the enzymatic activity. In spite of this, when basic $\mathrm{pH}$ was performed the Tris- $\mathrm{HCl}$ buffer was chosen than sodium phosphate due to higher enzyme activity in the same $\mathrm{pH} 8$, respectively 65 and $20 \mathrm{U} / \mathrm{mL}$. Xylanase residual activities linearly decreased after the incubation time (20, 40 and $60 \mathrm{~min}$ ) for all $\mathrm{pH}$ ranges (Fig. 4B). The loss of activity varied from $20-95 \%$ compared to control, and a higher loss was at $\mathrm{pH} 8$, after 60 min of incubation. In the range of $\mathrm{pH} 5-6$, the enzyme remained $80 \%$ active after all incubation times. Xylanases from other Trichoderma species was also found in literature with optimum $\mathrm{pH} 5-6$, but with broader $\mathrm{pH}$ ranges (Table 3 ).

Considering $\mathrm{pH}$ close to 5.0 as xylanase optimum $\mathrm{pH}$, some applications were found in literature. Zhang et al (2014) proposed the use of xylanases as an additive in bird feed, due to $\mathrm{pH}$ range used in this feed was 5.5-6.5. Other sectors are possible such as juice mills (Nagar et al., 2010) and bioethanol (Ferreira-Leitão et al., 2010; Carpio et al., 2019).

In this study, xylanase $T$. reesei QM9414 optimum activity was observed at $50{ }^{\circ} \mathrm{C}$ (Fig. 5A). This temperature is commonly reported by Trichoderma SC9 and T. inhamatum (Tab. 3), beyond microorganisms from other genera: Paenibacillus macquariensis (Terrasan et al., 2013) and Penicillium janczewskii (Jänis et al., 2001).

The Fig. 5B depicts the thermostability. In temperatures of $20-30{ }^{\circ} \mathrm{C}$, and after 20,40 and $60 \mathrm{~min}$, xylanase retained almost $80 \%$ of its activity. On the other hand, in temperatures higher than $50{ }^{\circ} \mathrm{C}$, a linear decrease in enzymatic activity was observed, except at the point at $50{ }^{\circ} \mathrm{C}$ for $20 \mathrm{~min}$, which the activity just improved slightly and then decreased again. Xylanase produced by T. reesei QM9414 showed optimum at $50{ }^{\circ} \mathrm{C}$ temperature of incubation. The low thermostability of xylanase by other species of Trichoderma was also observed in literature. 

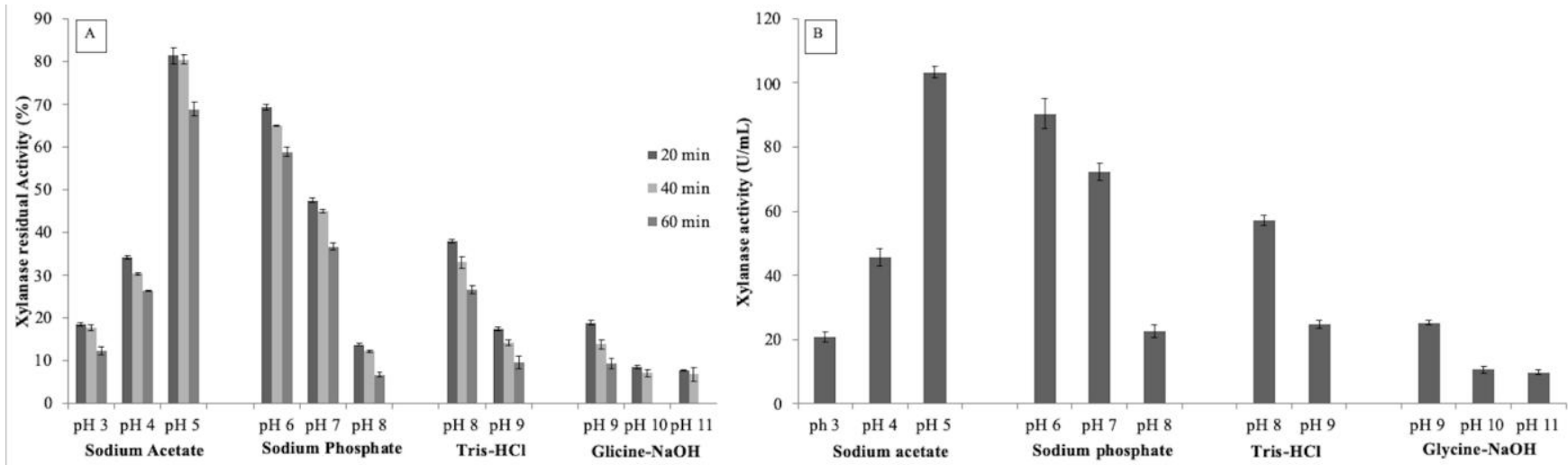

Fig. 4: A) Effect of pH on xylanase activity of the crude extract produced by T. reesei QM9414 cultivated with SS (pH $4.5,28^{\circ} \mathrm{C}, 288 \mathrm{~h}$ ). Each bar value was the average of three replicate experiments, and the error bars show the data ranges. B) Effect of pH on xylanase activity stability of the crude extract produced by T. reesei QM9414 cultivated with SS (pH 4.5, $28^{\circ} \mathrm{C}, 288 \mathrm{~h}$ ). Each bar value was the average of three replicate experiments, and the error bars show the data ranges.

Table 3: Comparative xylanase characteristics produced by different Trichoderma species in literature.

\begin{tabular}{ccccc}
\hline Microorganism & Optimum pH & Stability range pH & $\begin{array}{c}\text { Optimum } \\
\text { temperature }\left({ }^{\circ} \mathbf{C}\right)\end{array}$ & Reference \\
\hline T. reesei QM9414 & $\mathbf{5 . 0}$ & $\mathbf{5 . 0 - 6 . 0}$ & $\mathbf{5 0}$ & This work \\
T. inhamatum & Xyl I: $5-5.5$ & Xyl I: $4.5-6.5$ & 50 (both) & Silva et al., 2015 \\
Trichoderma sp SC9 & Xyl II: 5 & Xyl II: 5.0 & & \\
T. harzianum 1073 D3 & 5.0 & $3.5-9.0$ & 42.5 & Zhou et al., 2011 \\
T. reesei & 6.0 & $3.0-7.0$ & 60 & Isil and Nilufer, 2005 \\
\hline
\end{tabular}
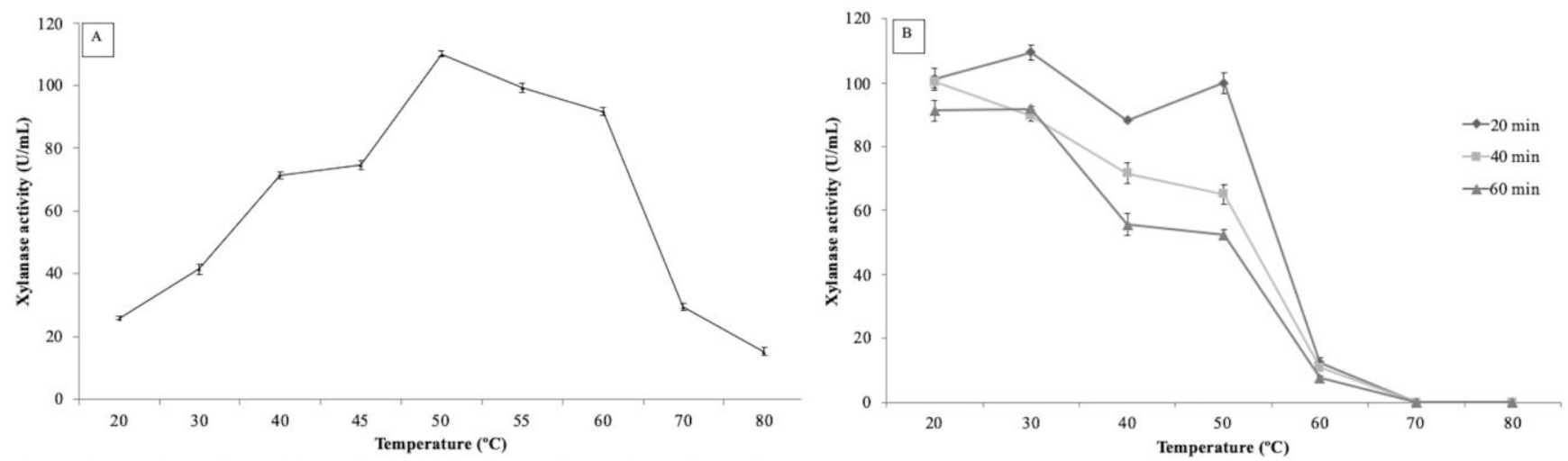

Fig. 5: A) Effect of temperature on xylanase activity produced from T. reesei QM9414. B) Thermostability of xylanase produced by T. reesei QM9414 ( $\mathrm{pH} 4.5,28^{\circ} \mathrm{C}, 288 \mathrm{~h}$ ). Each bar was the average of three replicate experiments, and the error bars show the data ranges.

The thermostability of $T$. inhamatum xylanase presented a half-life of $2.2 \mathrm{~h}$ at $40^{\circ} \mathrm{C}$, and subsequently when the temperature reached $50{ }^{\circ} \mathrm{C}$ this time dropped drastically to 2 min (Silva et al., 2015). Another work showed the stability of $T$. reesei RUT C-30 xylanase was $94 \%$ at $50{ }^{\circ} \mathrm{C}$ after 30 min of incubation (He et al., 2009). The thermostability loss of xylanase from Trichoderma genus in temperatures higher than $50{ }^{\circ} \mathrm{C}$ can be explained by a conformational structure change (Lopéz and Estrada, 2014), as well as the loss of secondary structure at $58.8^{\circ} \mathrm{C}$ and tertiary one in $56.3{ }^{\circ} \mathrm{C}$, reflecting in decrease of activity (Cobos and Estrada, 2003). Some additives in xylanases can be applied to solve the thermostability loss, such as polyhydroxylic co-solvents addiction (Xiong et al., 2004) and mutations in bisulfide bounds (Blanco et al., 1995). The effect of activation or inhibition of ions 
and EDTA on xylanases activities were evaluated and considering two ions solution concentrations, 5 and 10 mM. When the $\mathrm{Cu}^{2+}, \mathrm{Mg}^{2+}, \mathrm{Mn}^{2+}$ and $\mathrm{Zn}^{2+}$ ions were added, there was an increment on the enzymatic activity (Table 4). The most expressive result was the $\mathrm{Mn}^{2+}, 39$ and $49 \%$, for the respective concentrations. In contrast, 10 $\mathrm{mM}$ of ions $\mathrm{Cu}^{2+}$ and $\mathrm{Ag}^{+}$resulted in a strong inhibition of xylanase, 21 and $18 \%$ respectively. In literature, the presence of $\mathrm{Mn}^{2+}$ and $\mathrm{Zn}^{2+}$ also increased xylanase activity produced by $T$. harzianum 1073 D3, whereas in the presence of $\mathrm{Mg}^{2+}$ and $\mathrm{Cu}^{2+}$ the activity was not affected (Isil and Nilufer, 2005). According to Blanco et al. (1995) $\mathrm{Mn}^{2+}$ and $\mathrm{Cu}^{2+}$ did not affect the xylanase activity, while $\mathrm{Mg}^{2+}$ had a stimulatory effect. In addition, $\mathrm{Mn}^{2+}$ also stimulated the enzymatic activity for xylanases from Paenibacillus macquariensis (Terrasan et al., 2013). In this last work $\mathrm{Cu}^{2+}$ and $\mathrm{Fe}^{3+}$ caused inhibition on the enzymatic activity, whereas $\mathrm{Mn}^{2+}$ and $\mathrm{Mg}^{2+}$ presented no difference compared to control. EDTA caused a slightly decreased on the xylanase activity at concentrations of 5 and $10 \mathrm{mM}, 10$ and $0.8 \%$, respectively (Table 4). The explanation of the authors for this fact was that an enzyme needs divalent ions for catalysis. In other works, EDTA caused inhibition of the enzymatic activity of xylanases in the concentrations of 1, 2 and $10 \mathrm{mM}$ (Silva et al., 2008).

\subsection{Biobleaching}

In order to evaluate the xylanase efficiency for cellulose pulp biobleaching, the pulp was clarified by $T$. reesei QM9414 crude extract and 30 Units of xylanase per gram of pulp in 15 min was successfully effective compared to controls. Xylanase reduced the kappa number in $9.37 \%$ (2.1 kappa points). In literature, xylanase produced by $A$. caespitosus reduced kappa number only in $1.7 \%$ (xyl I), and the conditions were 10 $\mathrm{U} / \mathrm{g}$ dry pulp in 2 hours (Sandrim et al., 2005).

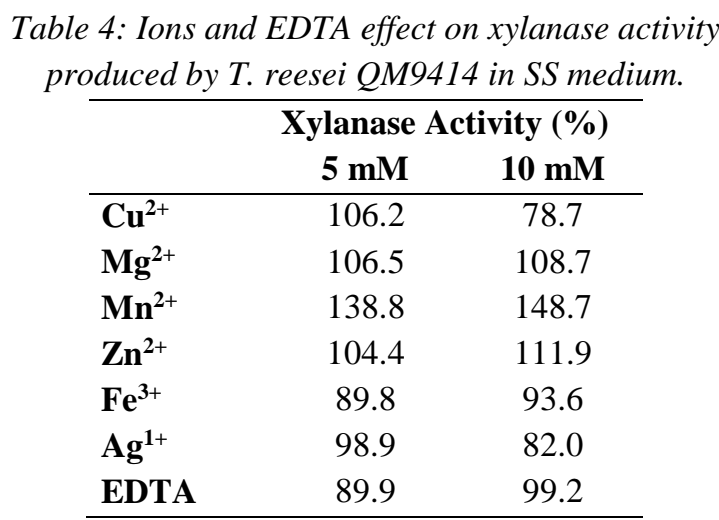

IV. CONCLUSIONS

Sugarcane straw was evaluated as the main carbon source in axenic SmF of T. reesei QM 9414 to produce fibrolytic enzymes in a simple and economical bioprocess. Also, the xylanase production was successfully scaled-up from shaker flasks to bioreactor, maintaining the same culture conditions, without loss of enzyme production. This enzyme was characterized, accordingly interesting conditions for some industrial applications, mainly potential on biobleaching of kraft pulp proposes.

\section{ACKNOWLEDGEMENTS}

The authors wish to thank Coordenação de Aperfeiçoamento de Pessoal de Nível Superior (Capes), Brazil, and Função de Amparo à Pesquisa (Fapesp 2014/24188-1), São Paulo, Brazil, for financial support.

\section{REFERENCES}

[1] Abdullah R., Nisar K., Aslam A., Iqtedar M. \& Naz S. (2015). Enhanced production of xylanase from locally isolated fungal strain using agro-industrial residues under solid-state fermentation. Nat Prod Res. 29, 1006-1011.

[2] Acharya S. \& Chaudhary A. (2012). Bioprospecting thermophiles for cellulase production: a review. Braz. J. of Microbiol. 43, 844-856.

[3] Ahamed A.\& Vermette P. (2008). Enhanced enzyme production from mixed cultures of Trichoderma reesei RUT-C30 and Aspergillus niger LMA grown as fed batch in a stirred tank bioreactor. Biochem. Eng. J. 42, 41-46.

[4] Anthony P., Harish B.S., Jampala P., Ramanujam S. \& Uppuluri K.B. (2016). Statistical optimization, purification and applications of xylanase produced from mixed bacteria in a solid liquid fermentation using Prosopis juliflora. Biocatal. Agric. Biotechnol. 8, 213220.

[5] Aquino G.S., Conti Medina C., Costa D.C., Shahab M. \& Santiago A.D. (2017). Sugarcane straw management and its impact on production and development of ratoons. (Supplement C), Ind Crops Prod.102, 58-64.

[6] Bailey M.J., Buchert J. \& Viikari L. (1993). Effect of pH on production of xylanase by Trichoderma reesei on xylanand cellulose-based media. Appl Microbiol Biotechnol. 40, 224-229.

[7] Blanco A., Vidal T., Colom J.F. \& Pastor F.I. (1995). Purification and properties of xylanase A from alkalitolerant Bacillus sp. strain BP-23. Appl Environ Microbiol. 61, 4468-4470.

[8] Campioni T.S., Moreira L.J., Moretto E., Nunes N.S.S. \& Oliva-Neto P. (2019). Biobleaching of Kraft pulp using fungal xylanases produced from sugarcane straw and the subsequent decrease of chlorine consumption. Biomass and Bioenergy, 121, 22-27.

[9] Carpio L.G.T. \& Souza F.S. (2019). Competition between Second-Generation Ethanol and Bioelectricity using the 
Residual Biomass of Sugarcane: Effects of Uncertainty on the Production Mix. Molecules, 24, 369.

[10] Carvalho A.F.A., Boscolo M., Silva R., Ferreira H. \& Gomes E. (2010). Purification and characterization of the $\alpha$-glucosidase produced by thermophilic fungus Thermoascus aurantiacus CBMAI 756. J Microbiol. 48, 452-459.

[11] Carvalho A.F.A., Gonçalves A.Z., Silva R. \& Gomes E. (2006). A specific short dextrin-hydrolyzing extracellular glucosidase from the thermophilic fungus Thermoascus aurantiacus 179-5. J Microbiol. 44, 276-283.

[12] Carvalho A.F.A., Neto P.O., Almeida P.Z., Silva J.B., Escaramboni B. \& Pastore G.M. (2015). Screening of xylanolytic Aspergillus fumigatus for prebiotic xylooligosaccharide production using bagasse. Food Technol Biotechnol. 53, 428-435.

[13] Carvalho D.M., Queiroz J.H. \& Colodette J.L. (2016). Assessment of alkaline pretreatment for the production of bioethanol from eucalyptus, sugarcane bagasse and sugarcane straw. Ind Crops Prod. 94, 932-941.

[14] Carvalho J.L.N., Nogueirol R.C., Menandro L.M.S., et al. (2017). Agronomic and environmental implications of sugarcane straw removal: a major review. GCB Bioenergy 9, 1181-1195.

[15] Choi J-M., Han S-S., Kim H-S. (2015). Industrial applications of enzyme biocatalysis: Current status and future aspects. Biotechnol Adv. 33, 1443-1454.

[16] Cobos A. \& Estrada P. (2003). Effect of polyhydroxylic cosolvents on the thermostability and activity of xylanase from Trichoderma reesei QM 9414. Enzyme Microb Tech. $33,810-818$

[17] Conab, Companhia Nacional de Abastecimento. 2019. Acompanhamento da safra brasileira de cana-de-açúcar. Conab Safra 2018/19 4, 1-75.

[18] Das A., Paul T., Halder S.K., et al. (2013). Production of cellulolytic enzymes by Aspergillus fumigatus ABK9 in wheat bran-rice straw mixed substrate and use of cocktail enzymes for deinking of waste office paper pulp. Bioresour Technol. 128, 290-296.

[19] Dewan S.S, 2018. (2019, October 02).Global Markets for Enzymes in Industrial Applications. Retrieved from: https://www.bccresearch.com/marketresearch/biotechnolo gy/global-markets-for-enzymes-in-industrialapplications.html.

[20] Dhillon G.S., Oberoi H.S., Kaur S., Bansal S. \& Brar S.K. (2011). Value-addition of agricultural wastes for augmented cellulase and xylanase production through solid-state tray fermentation employing mixed-culture of fungi. Ind Crops and Prod. 34, 1160-1167.

[21] Duff S.J.B., Cooper D.G. \& Fuller O.M. (1987). Effect of media composition and growth conditions on production of cellulase and $\beta$-glucosidase by a mixed fungal fermentation. Enzyme Microb Technol. 9, 47-52.

[22] Fernández-Núñez E.G., Barchi A.C., Ito S., et al. (2016). Artificial intelligence approach for high level production of amylase using Rhizopus microsporus var. oligosporus and different agro-industrial wastes. J. Chem. Technol. Biot. 92, 684-692.

[23] Ferreira-Leitão V., Perrone C.C., Rodrigues J., Franke A.P.M., Macrelli S. \& Zacchi G. (2010). An approach to the utilisation of $\mathrm{CO}_{2}$ as impregnating agent in steam pretreatment of sugar cane bagasse and leaves for ethanol production, Biotechnol. Biofuels 7, 2-8.

[24] Figueiredo E.B., Panosso A.R., Romão R. \& La Scala N. (2010). Greenhouse gas emission associated with sugar production in southern Brazil. Carbon Balance and Manag 5, 3.

Gankin E, (2019, October 18). Sustainability News. Retrieved from: https://www.biofutura.com/en/materials/sugarcane.

[25] Ghose T.K. (1987). Measurement of cellulase activities. Pure Appl Chem. 59, 257-268.

[26] Guerra G., Casado MR-LG., Arguelles J., Sánchez M.I., Manzano A.M. \& Guzman T. (2006). Cellulase production with sugarcane straw by Trichoderma citrinoviride on solid bed. Sugar Tech. 8, 30-35.

[27] Guimarães N.C.A., Sorgatto M., Peixoto-Nogueira S.C., et al. (2013). Bioprocess and biotecnology: effect of xylanase from Aspergillus niger and Aspergillus flavus on pulp biobleaching and enzyme production using agroindustrial residues as substract. Springer Plus 2, 380.

[28] Gutierrez-Correa M., Portal L., Moreno P., Tengerdy R.P. (1999). Mixed culture solid substrate fermentation of Trichoderma reesei with Aspergillus niger on sugar cane bagasse. Bioresour Technol. 68, 173-178.

[29] Haab D., Hagspiel K., Szakmary K. \& Kubicek C.P. (1990). Formation of the extracellular proteases from Trichoderma reesei QM 9414 involved in cellulase degradation. J Biotechnol. 16, 187-198.

[30] Haab D., Hagspiel K., Szakmary K. \& Kubicek C.P. (1990). Formation of the extracellular proteases from Trichoderma reesei QM 9414 involved in cellulase degradation. J Biotechnol. 16, 187-198.

[31] Hassuani S.J., Leal M.R.L.V. \& Macedo I.C. (2005). Biomass power generation: Sugar cane bagasse and trash. In: Série Caminhos para Sustentabilidade Piracicaba: PNUD-CTC, p.19-23.

[31] He J., Yu B., Fau - Zhang K., Zhang K., Fau - Ding X., Ding X., Fau - Chen D. \& Chen D. (2009). Expression of endo-1, 4-beta-xylanase from Trichoderma reesei in Pichia pastoris and functional characterization of the produced enzyme. BMC Biotechnology 16, 56-64.

[32] Hernández-Pérez A.F., Costa I.A.L., Silva D.D.V. et al. (2016). Biochemical conversion of sugarcane straw hemicellulosic hydrolyzate supplemented with cosubstrates for xylitol production. Bioresour Technol. 200, 1085-1088.

[33] Isil S., Nilufer A. 2005. Investigation of factors affecting xylanase activity from Trichoderma harzianum 1073 D3. Braz Arch Biol Technol. 48, 187-193.

[34] Jänis J., Rouvinen J., Leisola M., Turunen O. \& Vainiotalo P. (2001). Thermostability of endo-1,4- $\beta$-xylanase II from Trichoderma reesei studied by electrospray ionization Fourier-transform ion cyclotron resonance MS, 
hydrogen/deuterium-exchange reactions and dynamic light scattering. Biochem J. 356, 453.

[35] Knob A., Beitel S.M., Fortkamp D., Terrasan C.R.F., Almeida A.F. 2013. Production, purification, and characterization of a major Penicillium glabrum xylanase using Brewer's spent grain as substrate. BioMed Research International 728735, 8.

[36] Knob A., Fortkamp D., Prolo T., Izidoro S.C., Almeida J.M. 2014. Agro-residues as alternative for xylanase production by filamentous fungi. BioResources 9, 57385773.

[37] Leal M.R.L.V., Galdos M.V., Scarpare F.V., Seabra J.E.A., Walter A., Oliveira C.O.F. (2013). Sugarcane straw availability, quality, recovery and energy use: A literature review. Biomass and Bioenergy 53, 11-19.

[38] Li S., Yang X., Yang S., Zhu M., Wang X. 2012. Technology prospecting on enzymes: application, marketing and engineering. Comput. Sruct. Biotec. J. 2, 111.

[39] Lopéz G. \& Estrada P. (2014). Effect of temperature on xylanase II from Trichoderma reesei QM 9414: A calorimetric, catalytic, and conformational study. Enzyme Res. 2014, 16

[40] Macedo E.P., Cerqueira C.L.O., Souza D.A.J., Bispo A.S.R., Coelho R.R.R. \& Nascimento R.P. (2013). Production of cellulose-degrading enzyme on sisal and other agro-industrial residues using a new Brazilian actinobacteria strain Streptomyces sp. SLBA-08. Braz J of Chem Eng. 30, 729-735.

[41] Marín, F.R. et al. (2007). By-products from different citrus processes as a source of customized functional fibres. Food Chem, 100, 736-741.

[42] Miller G.L., Blum R., Glennon W.E. \& Burton A.L. (1960). Measurement of carboxymethylcellulase activity. Anal Biochem. 2.

[43] Nagar S., Gupta V.K., Kumar D., Kumar L., Kuhad R.C. (2010). Production and optimization of cellulase-free, alkali-stable xylanase by Bacillus pumilus SV-85S in submerged fermentation. J Ind Microbiol Biotechnol. 37, 71-83.

[44] Nagar S., Mittal A., Gupta V.K. 2012. Enzymatic clarification of fruit juices (Apple, Pineapple, and Tomato) using purified Bacillus pumilus SV-85S xylanase. Biotechnol Bioproc E.17,1165-1175.

[45] Nunes L.V., Correa F.F.B., Oliva-Neto P., et al. (2017). Lactic acid production from submerged fermentation of broken rice using undefined mixed culture. World $J$ Microbiol Biotechnol. 33, 79.

[46] Rahman, A. et al. (2017). Pretreatment of Wheat Bran for Suitable Reinforcement in Biocomposites. J. Renew. Mater. 5, n. Suppl 1, 62-73.

[47] Robl D., Delabona P.S., Costa P.S., et al. (2015). Xylanase production by endophytic Aspergillus niger using pentoserich hydrothermal liquor from sugarcane bagasse. Biocatal Biotransfor. 33, 175-187.

[48] Salmon, D.N.X., Fendrich, R.C., Cruz, M.A., Montibeller, V.W., Vandenberghe, L.P.S., Soccol C.R. \& Spier, M.R.
(2016). Bioprocess for phytase production by Ganoderma sp. MR-56 in different types of bioreactors through submerged cultivation. Biochem. Eng. J. 114, 288-297.

[49] Sandrim V.C., Rizzatti A.C.S., Terenzi H.F., Jorge J.A., Milagres A.M.F. \& Polizeli M.L.T.M. (2005). Purification and biochemical characterization of two xylanases produced by Aspergillus caespitosus and their potential for kraft pulp bleaching. Process Biochem. 40, 1823-1828.

[50] Sharma M., Mehta S. \& Kumar A. (2013). Purification and characterization of alkaline xylanase secreted from Paenibacillus macquariensis. Adv Microbiol. 3, 3241.

[51] Silva D.F., Camargo R., Carvalho A.F.A. \& Oliva-Neto P. (2013). Cellulolytic enzyme production by the fungi Trichoderma reesei QM9414 and Trichoderma reesei CCT2768 using citrus pulp. Poster presented at the 6th Symposium of Applied Microbiology Rio Claro, SP, Brazil.

[52] Silva D.F., Hergesel L.M., Campioni T.S., Carvalho A.F.A. \& Oliva-Neto P. (2018). Evaluation of different biological and chemical treatments in agroindustrial residues for the production of fungal glucanases and xylanases. Process Biochem. 67, 29-37.

[53] Silva L.A.O., Carmona E.C. [2008]. Production and characterization of cellulase-free xylanase from Trichoderma inhamatum. Appl Biochem Biotechnol.150,117-125.

[54] Silva, L.A.O., Terrasan C.R.F., Carmona E.C. (2015). Purification and characterization of xylanases from Trichoderma inhamatum. Electron J Biotechnol.18, 307313.

[55] Szczerbowski, D. et al. (2014). Sugarcane biomass for biorefineries: Comparative composition of carbohydrate and non-carbohydrate components of bagasse and straw. Carbohydr. Polym. 114, 95-101.

[56] Terrasan C.R.F., Temer B., Sarto C., Silva Júnior F.G., Carmona E.C. (2013). Xylanase and $\beta$-xylosidase from Penicillium janczewskii: production, physico-chemical properties, and application of the crude extract to pulp biobleaching. BioResources 8, 1292-1305.

[57] Wen Z., Liao W. \& Chen S. Production of cellulase/ $\beta$ glucosidase by the mixed fungi culture of Trichoderma reesei and Aspergillus phoenicis on dairy manure. 2005. In: Davison B.H., Evans B.R., Finkelstein M., McMillan J.D., (Eds). Twenty-Sixth Symposium on Biotechnology for Fuels and Chemicals, Humana Press, Totowa, pp. 93104.

[58] Xiong H., Fenel F., Leisola M., Turunen O. 2004. Engineering the thermostability of Trichoderma reesei endo-1,4- $\beta$-xylanase II by combination of disulphide bridges. Extremophiles 8, 393-400.

[59] Xiong L., Kameshwar A.K.S., Chen X., et al. (2016). The ACEII recombinant Trichoderma reesei QM9414 strains with enhanced xylanase production and its applications in production of xylitol from tree barks. Microb Cell Fact.15, 215. 
[60] Zhang L., Wang X., Ruan Z., et al. (2014). Fungal cellulase/xylanase production and corresponding hydrolysis using pretreated corn stover as Substrates. Appl Biochem Biotechnol. 172, 1045-1054.

[61] Zhou P., Zhu H., Yan Q., Katrolia P., Jiang Z. 2011. Purification and properties of a psychrotrophic Trichoderma sp. xylanase and its gene sequence. Appl Biochem Biotechnol. 164, 944-956. 
